\author{
ELŻBIETA FERET \\ ORCID: 0000-0001-9283-0316 \\ Uniwersytet Rzeszowski \\ eferet@ur.edu.pl
}

\title{
Niepomijalność organów administracji publicznej w zakresie ujawniania informacji dotyczących finansów publicznych w Polsce
}

\begin{abstract}
Abstrakt: Przedmiotem opracowania jest wskazanie wybranych przejawów działalności organów administracji publicznej w zakresie dostarczania informacji o finansach publicznych w Polsce w celu udowodnienia tezy niemożności pomijania działań zarówno rządowych, jak i samorządowych organów administracji publicznej na każdej płaszczyźnie funkcjonowania państwa.

Analiza wybranej problematyki zostanie przeprowadzona na podstawie jednej z zasad budżetowych — zasady jawności budżetu. Z uwagi na rozszerzenie jej znaczenia także na jawność i przejrzystość finansów publicznych rozważania będą się opierać na poprzednio i aktualnie obowiązujących przepisach prawa w kontekście działań organów administracji publicznej.

Podstawą rozważań będą obowiązujące unormowania prawne związane przede wszystkim z finansami publicznymi, lecz także wynikające z innych aktów normatywnych, wybrane pozycje literatury przedmiotu oraz orzecznictwo sądowe. Te źródła najlepiej bowiem potwierdzą przyjętą tezę o niepomijalności działań organów publicznych również w obszarze funkcjonowania polskich finansów publicznych.
\end{abstract}

Słowa kluczowe: organy administracji publicznej, zasada jawności i przejrzystości finansów publicznych, dostęp do informacji publicznej.

\section{Wstęp}

Opracowanie ma na celu wykazanie konieczności podejmowania działań przez organy administracji publicznej w zakresie ujawniania informacji związanych z funkcjonowaniem polskich finansów publicznych. Wybrany temat wpisuje się tym samym w udowodnienie tezy niepomijalności administracji publicznej, bę- 
dącej tematem przewodnim konferencji jubileuszowej z okazji pięćdziesięciolecia działalności Instytutu Nauk Administracji Uniwersytetu Wrocławskiego. Przyjęta problematyka konferencji jest jak najbardziej uzasadniona, albowiem funkcjonowanie organów administracji publicznej tworzy niezaprzeczalną gwarancję wykonywania zadań publicznych stojących zarówno przed państwem, jak i jednostkami samorządu terytorialnego. $\mathrm{Z}$ uwagi na to za tezę opracowania należy uznać brak uprawnienia do pomijania informacji o czynnościach wykonywanych przez organy administracji publicznej, gdyż to właśnie od ich jawnego funkcjonowania uzależnione jest właściwe — zgodne z przepisami prawa — działanie państwa.

Aby udowodnić przyjętą tezę, celem autorki niniejszego opracowania będzie wskazanie na przykładzie wybranych unormowań prawnych — finansów publicznych — obowiązków, zjakimi muszą zmierzyć się organy administracji publicznej zarówno szczebla państwowego, jak i samorządowego. W tym względzie zostanie przeprowadzona krótka analiza ich działalności udowadniająca konieczność jawnego i przejrzystego funkcjonowania finansów publicznych w Polsce. Rozważania zawarte w opracowaniu znajdą potwierdzenie w obowiązujących regulacjach prawnych, doktrynie przedmiotu oraz orzecznictwie sądowym. Całość przeprowadzonych rozważań zostanie podsumowana w sformułowanych wnioskach de lege lata i postulatach de lege ferenda, potwierdzających niemożność pomijania działania organów administracji publicznej także w sferze finansów publicznych.

\section{Geneza zasady jawności i przejrzystości budżetu}

Wstęp do prowadzonych rozważań musi stanowić określenie podstawy prawnej oraz faktycznych uwarunkowań przesądzających o konieczności jawnego funkcjonowania finansów publicznych. Dlatego analizę należy rozpocząć od wskazania korzeni doktrynalnych i prawnych takiego działania organów administracji publicznej. Z uwagi na obszerność problematyki oraz wymogi redakcyjne rozważania zostaną ograniczone jedynie do aktualnych regulacji prawnych z pewnym odniesieniem się do poprzednio wypracowanych poglądów doktryny, która zapoczątkowała jawność i przejrzystość również w sprawach związanych z funkcjonowaniem finansów publicznych.

Realizacja zadań publicznych ze środków publicznych odbywa się na podstawie przepisów wynikających z unormowań ustawy o finansach publicznych ${ }^{1}$. Regulacje prawne mające źródło we wskazanym akcie prawnym tworzą merytoryczną podstawę wyodrębnienia pewnych zasad, tak zwanych budżetowych ${ }^{2}$,

${ }^{1}$ Ustawa z dnia 27 sierpnia 2009 roku o finansach publicznych, tekst jedn. Dz.U. z 2019 r. poz. 869 ze zm. (dalej: u. o f.p.).

2 Pod tym pojęciem należy rozumieć, za doktryną, reguły niekiedy przybierające postać jedynie postulatów (na przykład przy zasadzie równowagi budżetowej), które powinny być przestrze- 
które mają stać na straży właściwie gromadzonych i wydatkowanych środków publicznych $^{3}$. Realizacja każdej z tych zasad budżetowych jest uzależniona od działalności organów administracji publicznej państwowych i samorządowych ${ }^{4}$.

Wśród ośmiu obecnie eksponowanych zasad budżetowych, znajdujących potwierdzenie $\mathrm{w}$ aktualnych unormowaniach prawnych, za jedną $\mathrm{z}$ ważniejszych $\mathrm{w}$ erze wszechobecnej potrzeby zapewnienia dostępu do informacji związanych z funkcjonowaniem organów administracji publicznej należy uznać wskazaną już zasadę jawności i przejrzystości budżetu. Sięga ona korzeniami doktryny prawa finansowego lat pięćdziesiątych ubiegłego wieku ${ }^{5}$, która wskazywała ${ }^{6}$ na konieczność zapewnienia ,wglądu ludu pracującego miast i wsi w kierownictwo, w postępowanie władz i organów państwowych, w szczególności w związku z funkcjonowaniem budżetu państwa"7. W praktyce realizacja tego postulatu ujawniania informacji finansowych odbiegała od doktryny, mając na celu stworzenie rodzaju propagandy otwartości państwa w stosunku do obywateli. Ten sztuczny trend był podtrzymywany także w okresie PRL-u — aż do 1989 roku $^{8}$, kiedy rządy sprawowała komunistyczna Polska Partia Robotnicza, a następnie Polska Zjednoczona Partia Robotnicza ${ }^{9}$ jako część struktur Układu Warszawskiego podlegającego dowództwu Armii Radzieckiej ${ }^{10}$. Wówczas funkcjonujący system scentralizowanej władzy nie dążył bowiem do ujawniania informacji dotyczących ich funkcjono-

gane w celu właściwego, czyli zgodnego z przepisami prawa, prowadzenia gospodarki finansowej zarówno na szczeblu państwowym, jak i samorządowym. Na ten temat zob. m.in. E. Denek, System budżetowy i gospodarka budżetowa państwa, [w:] Finanse publiczne, red. E. Denek, Warszawa 1997, s. 49; N. Gajl, Finanse i prawo finansowe, Warszawa 1986, s. 108; J. Jaśkiewiczowa, Prawo finansowe, Gdańsk 1990, s. 32; E. Ruśkowski, J. Stankiewicz, Budżety jednostek samorządu terytorialnego, [w:] Finanse publiczne i prawo finansowe, red. E. Ruśkowski, Warszawa 2000, s. 135.

3 Zgodnie z definicją wynikającą z treści art. 3 u.of.p., wskazującej na to, że finanse publiczne to procesy związane $\mathrm{z}$ gromadzeniem środków publicznych oraz ich rozdysponowywaniem.

${ }^{4}$ Mowa o zasadzie uprzedniości budżetu, roczności budżetu, równowagi budżetowej, szczegółowości budżetu, powszechności budżetu, jedności materialnej budżetu, jedności formalnej budżetu oraz jawności budżetu.

5 J. Zdzitowiecki, Zasady budżetowe w Konstytucji Polskiej Rzeczypospolitej Ludowej, s. 33, https://repozytorium.amu.edu.pl/bitstream/10593/15335/1/003\%20JAN\%20ZDZITOWIECKI\%20 RPEiS\%2020\%282\%29\%2C\%201958.pdf (dostęp: 2.03.2019).

${ }^{6} \mathrm{Na}$ gruncie obowiązującej wówczas Konstytucji Polskiej Rzeczypospolitej Ludowej z dnia 22 lipca 1952 roku (Dz.U. Nr 33, poz. 232) ustanowiony został ustrój polityczny oraz społeczno-gospodarczy państwa, w którym władze i organy, prawa i obowiązki obywateli oraz tworzone postanowienia stały się podstawą systemu budżetowego. Tak S. Rozmaryn, Polskie prawo państwowe, Warszawa 1951, s. 285.

7 Z. Pirożyński, Budżet państwowy w projekcie Konstytucji, „Finanse” 1952, nr 2, s. 22; oraz M. Maneli, O funkcjach państwa, Warszawa 1962, s. 54 n., 197 n.

8 A. Gella, Zagłada Drugiej Rzeczypospolitej 1945-1947, Warszawa 1998, s. 89.

9 A. Paczkowski, Stanisław Mikołajczyk, czyli klęska realisty (zarys biografii politycznej), Warszawa 1991, s. 203.

10 Szerzej zob. m.in. S. Weremiuk, Specyfika stosunków polsko-radzieckich w okresie 19441991, „Przegląd Bezpieczeństwa Wewnętrznego” 2014, nr 11, s. 43-57. 
wania, wręcz przeciwnie - udostępniał jedynie informacje nazywane propagandą sukcesu' ${ }^{11}$.

Dopiero lata dziewięćdziesiąte ${ }^{12}$ przyniosły dostrzegalną zmianę w tym zakresie. Na ten okres przypada wskazanie i uznanie za niezwykle istotną zasady jawności budżetu. Początkowo bowiem tak traktowała ją doktryna, odnosząc jej treść wyłącznie do konieczności jawnego działania organów administracji publicznej w stosunku do informacji zawartych w budżecie ${ }^{13}$. W myśl przyjętych w 1991 roku regulacji Prawa budżetowego ${ }^{14}$ ustawodawca nie wskazywał wprawdzie enumeratywnie, na czym ma polegać jawność informacji zawartych w planach finansowych państwa lub budżecie gminy, jednak wprowadzał pewne unormowania prawne, które eksponowały potrzebę ujawnienia informacji tam zawartych. Jako przykład można podać proces uchwalania budżetu państwa w formie ustawy budżetowej, budżetu gminy zaś w formie uchwały, które zgodnie z przepisami prawa winny były być ogłaszane odpowiednio w Dzienniku Ustaw oraz Wojewódzkim Dzienniku Urzędowym ${ }^{15}$, a co za tym idzie — to właściwe organy administracji publicznej musiały zadbać o przygotowanie, ale i przekazanie informacji w tym zakresie ${ }^{16}$.

Podobnie z ustanowionego Prawa budżetowego wynikało wprost, że minister finansów został zobligowany między innymi do ogłaszania wysokości stawek należności budżetowych i składek na państwowe fundusze celowe przed rozpoczęciem roku budżetowego, w którym należności te były wymagalne ${ }^{17}$. Także prezydia gminnych, miejskich i dzielnicowych oraz powiatowych rad narodowych, czyli ówczesne organy administracji publicznej ${ }^{18}$, zostały zobowiązane do udostępniania ludności nieodpłatnie wskazanych aktów normatywnych ${ }^{19}$. Inną kwestią jest dość niskie zainteresowanie społeczeństwa sprawami społecznymi, w tym budżetem, stąd postulowana przez ówczesną literaturę konieczność odwołania się do instynktu politycznego ludzi, bez którego nie będzie można przejść na wyższy etap reform systemowych ${ }^{20}$.

11 „Aby Polska rosła w siłę, a ludzie żyli dostatniej” - A. Chwalba et al., Dzieje Polski. Kalendarium, Kraków 2000, s. 787. Na ten temat zob. także W. Roszkowski, Najnowsza historia Polski 1914-1945, Warszawa 2003, s. 678-680.

12 M. Szumiło, Roman Zambrowski 1909-1977, Warszawa 2014, s. 247.

13 Rozumianym jako roczny plan finansowy. Zob. J. Jaśkiewiczowa, op. cit., s. 37.

14 Ustawa z dnia 5 stycznia 1991 roku Prawo budżetowe, tekst jedn. Dz.U. z 1993 r. Nr 72, poz. 344 ze zm.

15 Art. 1 ust. 1 pkt 1 ustawy z dnia 30 grudnia 1950 roku o wydawaniu Dziennika Ustaw Rzeczypospolitej Polskiej i Dziennika Urzędowego Rzeczypospolitej Polskiej „Monitor Polski”, Dz.U. $\mathrm{Nr} 58$, poz. 524 ze zm.

16 Odpowiednio art. 34 oraz art. 37 ustawy Prawo budżetowe z 1991 roku.

17 Wynika z treści art. 33 ust. 7 ustawy Prawo budżetowe.

18 Szerzej na ten temat zob. E. Sokalska, Organizacja lokalnego aparatu administracyjnego w Polsce w latach 1957-1975, „Studia Prawnoustrojowe” 2005, nr 4, s. 45-55.

19 Por. art. 7 ustawy o wydawaniu Dziennika Ustaw Rzeczypospolitej Polskiej i Dziennika Urzędowego Rzeczypospolitej Polskiej „Monitor Polski”.

20 Za: W. Morawski, Zmiana instytucjonalna, Warszawa 2000, s. 159. 


\section{Znaczenie jawności finansów publicznych obecnie}

\subsection{Zasada jawności budżetu}

W świetle obowiązujących regulacji prawnych łatwo zauważyć, że rozumienie zasady jawności budżetu ${ }^{21}$ zostało dość mocno rozszerzone w stosunku do jej pierwotnego znaczenia na jawność finansów publicznych ${ }^{22}$. Taki wniosek wynika z co najmniej dwóch kwestii. Po pierwsze, ustawodawca w obowiązującej u. o f.p., analogicznie jak w poprzednich ${ }^{23}$, wprowadza odrębny rozdział 4 poświęcony wyłącznie kwestiom ujawniania i przejrzystości finansów publicznych (tak też zatytułowany). Po drugie zaś, dotychczasową zasadę jawności budżetu rozszerza na jawność oraz przejrzystość finansów publicznych, a nie tylko budżetu.

Pozornie zabieg ustawodawcy może wydawać się mało znaczący z punktu widzenia pierwotnego znaczenia i rozumienia zasady jawności budżetu, jednakże warto uzmysłowić sobie, jak mocno ustawodawca podkreśla obecnie znaczenie jawności informacji związanych z finansami publicznymi. W tym względzie można uporządkować rozważania, rozpoczynając od wskazania zakresu przedmiotowego tytułowej jawności i przejrzystości.

Jak podniesiono już wcześniej, obowiązujące regulacje prawne odnoszą się już nie tylko do budżetu ${ }^{24}$, rozumianego $\mathrm{w}$ doktrynie ${ }^{25}$ jako roczny plan finansowy obejmujący dochody i wydatki oraz przychody i rozchody odpowiednio państwa lub jednostki samorządu terytorialnego, lecz do całych finansów publicznych. Finanse publiczne należy bowiem za ustawą o finansach publicznych rozu-

21 Na która powołują się także sądy; zob. m.in. wyrok NSA z dnia 17 października 2017 roku, sygn. II GSK 11/16, http://orzeczenia.nsa.gov.pl/doc/BF7A8DE8E7 (dostęp: 2.03.2019).

22 Zob. także wyrok WSA w Gdańsku z dnia 19 sierpnia 2015 roku, sygn. II SA/Gd 373/15, http://orzeczenia.nsa.gov.pl/doc/551CA4E29B (dostęp: 3.03.2019); oraz wyrok NSA z dnia czerwca 2015 roku, sygn. I OSK 1608/14, http://orzeczenia.nsa.gov.pl/doc/C344A59C7E (dostęp: 3.03. 2019).

23 Mowa o rozdziałach 2 ustawy o finansach publicznych odpowiednio: z dnia 26 listopada 1998 roku (tekst jedn. Dz.U. z 2003 r. Nr 15, poz. 148 ze zm.) oraz z dnia 30 czerwca 2005 roku (Dz.U. Nr 249, poz. 2103, 2104).

24 Pojęcie „budżet” pochodzi od łacińskiego słowa bulga, które znaczyło torbę, koszyczek do zbierania dochodów. Zob. K. Kumaniecki, Stownik łacińsko-polski, Warszawa 1986, s. 69; oraz W. Kopaliński, Stownik wyrazów obcych i zwrotów obcojęzycznych z almanachem, Warszawa 2000, s. 82.

25 Jako jeden z pierwszych pojęcie budżetu zdefiniował znany teoretyk budżetu René Stourm. W swoim dziele Le budget ustalił zasady gospodarki budżetowej. Opowiadał się za określeniem, w którym istniałyby dwa odrębne człony definicji budżetu: jeden stanowiły przewidywane roczne dochody i wydatki, drugi — forma zatwierdzenia i aprobaty udzielana rządowi; zob. idem, Le budget, Paris 1913, s. VI. Przy tym określenie budżetu w ujęciu ekonomicznym można tłumaczyć także jako plan finansowy państwa, fundusz, akt prawny; zob. m.in. D. Begg, S. Fischer, R. Dornbusch, Mikroekonomia, Warszawa 2007, s. 82; Z. Dych, B. Szopa, Encyklopedia zarządzania, Kraków 2004, s. 92. 
mieć jako procesy związane z gromadzeniem środków publicznych i ich wydatkowaniem. Dlatego też, jak można wywnioskować, jawny i przejrzysty ma być nie tylko roczny budżet, lecz także reguły oraz sposoby dotyczące pozyskiwania i rozdysponowywania środków publicznych ${ }^{26}$.

Ponadto potwierdzenie ogromnego znaczenia jawności finansów publicznych można znaleźć w regulacjach wynikających z treści art. 33 ust. 1 u. o f.p., zgodnie z którym „Gospodarka środkami publicznymi jest jawna”. Dzięki tej regulacji (choć mocno nieprecyzyjnej, gdyż ustawodawca posługuje się pojęciem gospodarki i gospodarowania środkami publicznymi bez ich odróżnienia) ${ }^{27}$ oczywiste jest, że we wszystkich przypadkach, w których występują środki publiczne (niekoniecznie pozostające tylko w dyspozycji jednostek sektora finansów publicznych $)^{28}$, nieuniknione jest zachowanie zasady jawności. Zasada ta sankcjonuje bowiem wymóg informowania o działalności finansowej władz publicznych oraz prezentacji zjawisk finansowych w sposób umożliwiający kontrolę i ocenę tej działalności nie tylko przez parlament, lecz także przez społeczeństwo ${ }^{29}$.

Istotne znaczenie dla zapewnienia jawnego (powszechnego) ${ }^{30}$ dostępu do informacji związanych ze środkami publicznymi mają także unormowania prawne, które wskazują enumeratywnie, ale w ramach katalogu otwartego przejawy tej jawności. Za art. 34 ust. 1 u. o f.p. zasada jawności gospodarowania środkami publicznymi jest realizowana w szczególności przez: jawność debaty budżetowej w Sejmie i Senacie oraz debat budżetowych w organach stanowiących jednostek samorządu terytorialnego; jawność debaty nad sprawozdaniem z wykonania budżetu państwa w Sejmie i debat nad sprawozdaniami z wykonania budżetów jednostek samorządu terytorialnego; podawanie do publicznej wiadomości: kwot dotacji udzielanych z budżetu państwa i budżetów jednostek samorządu terytorialnego, kwot dotacji udzielanych przez państwowe fundusze celowe, zbiorczych danych dotyczących finansów publicznych, informacji o wykonaniu budżetu państwa za okresy miesięczne; jawność debaty nad projektem uchwały w sprawie

${ }^{26}$ Określonych w art. 5 i 6 u. o f.p., a skonkretyzowanych odpowiednio w art. 111-112 oraz art. 216 ust. 1 i 2 u. o f.p.

27 Zgodnie z rozumieniem słownikowym pojęcie gospodarki oznacza gospodarowanie, dysponowanie czymś, w tym wypadku środkami publicznymi. Zob. Wielki słownik języka polskiego, Warszawa 2006, s. 237.

${ }^{28} \mathrm{Na}$ gruncie obowiązujących regulacji prawnych ustawodawca w art. 4 ust. 1 przewiduje, że przepisy u. o f.p. stosuje się do: jednostek sektora finansów publicznych oraz innych podmiotów w zakresie, w jakim wykorzystują środki publiczne lub dysponują tymi środkami. Przepis ten koreluje z unormowaniami ustawy odpowiedzialności za naruszenie dyscypliny finansów publicznych i pociąga za sobą konsekwencje rozszerzenia odpowiedzialności za naruszenie dyscypliny finansów publicznych także na te inne podmioty. Zob. art. 4 ust. 1 pkt 4 ustawy z dnia 17 grudnia 2004 roku o odpowiedzialności za naruszenie dyscypliny finansów publicznych (tekst jedn. Dz.U. z 2019 r. poz. 1440 ze zm.), który przewiduje odpowiedzialność również tych podmiotów.

29 J. Gliniecka, Przejrzystość i jawność jako reguły gospodarowania publicznymi środkami pieniężnymi, „Gdańskie Studia Prawnicze” 2015, nr 33, s. 161 n.

30 Można traktować jako synonim pojęcia jawności. 
wieloletniej prognozy finansowej jednostki samorządu terytorialnego ${ }^{31}$. Podmioty zobowiązane do działania w tym zakresie zostaną scharakteryzowane w dalszej części prowadzonych rozważań.

W tym zakresie niezwykle ważne jest także udowodnienie konieczności zapewnienia jawnego dostępu do informacji związanych ze środkami publicznymi w konotacji z przepisami wynikającymi z ustawy z dnia 6 września 2001 roku o dostępie do informacji publicznej ${ }^{32}$. Jak bowiem można wynieść z treści art. 2 ust. 1 tej ustawy, każdemu przysługuje prawo dostępu do informacji publicznej, zwane dalej ,prawem do informacji publicznej”, przy czym nie musi on wykazywać interesu prawnego lub faktycznego odnośnie do pozyskania informacji ${ }^{33}$ — jest to jego prawo podmiotowe zagwarantowane w art. 61 ust. 1 Konstytucji Rzeczypospolitej Polskiej ${ }^{34}$. Przywołany przepis przyznaje prawo do informacji obejmującej również kwestie związane z działalnością organów samorządu gospodarczego i zawodowego, a także innych osób oraz jednostek organizacyjnych w zakresie, w jakim wykonują one zadania władzy publicznej i gospodarują mieniem komunalnym lub majątkiem Skarbu Państwa ${ }^{35}$.

Prawo do informacji zostało dodatkowo rozszerzone w art. 61 ust. 2 Konstytucji RP, na mocy którego prawo do uzyskiwania informacji obejmuje również dostęp do dokumentów oraz wstęp na posiedzenia kolegialnych organów władzy publicznej pochodzących z powszechnych wyborów, z możliwością rejestracji

31 Aczkolwiek nie należy zapominać, że tak szeroko rozumiana jawność finansów publicznych podlega ustawowemu ograniczeniu. Jak wynika bowiem z treści art. 33 ust. 2 u. o f.p., gospodarka środkami publicznymi nie jest jawna w stosunku do środków publicznych, których pochodzenie lub przeznaczenie zostało uznane za informację niejawną na podstawie odrębnych przepisów, lub jeżeli wynika to $\mathrm{z}$ umów międzynarodowych. Na ten temat por. wyrok WSA w Lublinie z dnia 29 października 2015 roku, sygn. II SA/Lu 637/15, http://orzeczenia.nsa.gov.pl/doc/E41AD5952E (dostęp: 3.03.2019).

32 Tekst jedn. Dz.U. z 2019 r. poz.1429 ze zm.

33 Zgodnie z treścią ust. 2 ustawy o dostępie do informacji publicznej.

34 Konstytucja Rzeczypospolitej Polskiej z dnia 2 kwietnia 1997 roku, Dz.U. Nr 78, poz. 483 ze zm. (dalej: Konstytucja RP).

35 Szerzej zob. m.in. M. Mucha, Obowiazki administracji publicznej w sferze dostepu do informacji, Wrocław 2002, s. 57. Na ten temat zob. także treść wyroku NSA, w którym stwierdza się, że „informacją publiczną będzie każda wiadomość wytworzona lub odnoszona do władz publicznych, a także wytworzona lub odnoszona do innych podmiotów wykonujących funkcje publiczne w zakresie wykonywania przez nie zadań władzy publicznej i gospodarowania mieniem komunalnym lub mieniem Skarbu Państwa. Informacja publiczna dotyczy sfery faktów. Jest nią treść dokumentów wytworzonych przez organy władzy publicznej i podmioty niebędące organami administracji publicznej, treść wystąpień, opinii i ocen przez nie dokonywanych, niezależnie do jakiego podmiotu są one kierowane i jakiej sprawy dotyczą. Informację publiczną stanowi treść wszelkiego rodzaju dokumentów odnoszących się do organu władzy publicznej, związanych z nim bądź w jakikolwiek sposób dotyczących go. Są nią zarówno treści dokumentów bezpośrednio przez organ wytworzonych, jak i te, których używa się przy realizacji przewidzianych prawem zadań (także te, które tylko w części go dotyczą), nawet gdy nie pochodzą wprost od niego" - wyrok NSA z dnia 7 marca 2012 roku, sygn. I OSK 2265/11, http://orzeczenia.nsa.gov.pl/doc/BFC87465F2. 
dźwięku lub obrazu. To unormowanie w sposób oczywisty wiąże się ze wskazanymi wcześniej regulacjami szczegółowymi ustawy o finansach publicznych, będąc potwierdzeniem możliwości udziału w debatach odpowiednio sejmowych lub jednostek samorządu terytorialnego.

Podawanie informacji związanych z gospodarką finansową państwa oraz jednostek samorządu terytorialnego odbywa się przy uwzględnieniu wskazanych regulacji konstytucyjnych i przepisów ustawy o dostępie do informacji publicznej. Przyjmują one, że każdy może uzyskać takie informacje przy wykorzystaniu kilku sposobów. Przede wszystkim każdemu przysługuje prawo do korzystania ze stron internetowych Biuletynu Informacji Publicznej (dalej: BIP), bezpośrednio Ministerstwa Finansów albo poszczególnych jednostek samorządowych przy zachowaniu możliwości wstępu na posiedzenia organów kolegialnych pochodzących z wyborów powszechnych. Ponadto istnieje możliwość zapoznania się z dokumentami udostępnionymi przez wyłożenie lub ogłoszenie w miejscach publicznie dostępnych. W sytuacji nieudostępnienia informacji na stronach BIP informacja podlega też udostępnieniu na wniosek o udostępnienie informacji publicznej ${ }^{36}$.

\subsection{Przejrzystość finansów publicznych}

Z kolei przejrzystość finansów publicznych ${ }^{37}$ należy utożsamiać z takim uporządkowaniem środków publicznych, aby każdy podmiot, zarówno należący do sektora finansów publicznych, jak i jedynie „dopuszczony” do wykorzystywania lub dysponowania środkami publicznymi, miał dostęp do informacji odnośnie do wysokości kwot tych środków finansowych na dany rok budżetowy ${ }^{38}$. Taki wniosek jest uprawniony na mocy regulacji wynikających z treści art. $114 \mathrm{w} \mathrm{zW}$. z art. 39 u. o f.p. Przyjęte tam unormowania prawne wskazują bowiem wprost na konieczność podziału budżetu państwa na części budżetowe, na czele których ma stać dysponent części budżetowej, czyli podmiot, jednostka uprawniona do gro-

${ }^{36}$ Szerzej zob. K. Kędzierska, Prawo do informacji w polskim porzadku prawnym, [w:] Dostęp do informacji publicznej a prawo do prywatności, red. A. Gałach et al., Warszawa 2015, s. 1-16.

37 Zasada przejrzystości oznacza stosowanie jednolitych kryteriów klasyfikacji dla dochodów i wydatków budżetowych oraz innych przychodów i rozchodów. Wskazuje również na konieczność jasnych i jednolitych reguł rachunkowości i sprawozdawczości przez podmioty sektora samorządowego; zob. L. Patrzałek, Finanse samorzadowe, Wrocław 1999, s. 57.

38 Należy to łączyć z zasadą szczegółowości budżetu. Szczegółowość budżetu zaś trzeba wiązać z zasadą specjalizacji oraz operatywności. Zasada specjalizacji dochodów i wydatków oznacza, że dochody i wydatki budżetowe powinno się planować i wykonywać w ramach szczegółowego ich układu, dostosowanego do układu zadań w narodowym planie społeczno-gospodarczym. Zasada operatywności wyraża natomiast potrzebę opracowania budżetu w układzie umożliwiającym ścisłe ustalenie, które jednostki są odpowiedzialne za wykonanie poszczególnych zadań budżetowych i jakie środki otrzymają one na sfinansowanie tych zadań. Dopiero ich dopełnieniem jest zasada szczegółowości budżetu. Zob. J. Wierzbicki, J. Wolniak, Finanse w socjalizmie - zarys teorii, Warszawa 1979, s. 234. 
madzenia i wydatkowania środków publicznych w ramach swoich części, określonych rozporządzeniem przez ministra finansów ${ }^{39}$. Dysponenci rozumiani przez ustawę jako właściwi ministrowie, kierownicy urzędów centralnych, wojewodowie $^{40}$ uzyskują niezbędne dane co do środków finansowych, które porządkują (zgodnie z art. 39 u. o f.p.) w ramach klasyfikacji budżetowej. Dzięki podziałowi na działy, rozdziały i paragrafy każdy podmiot podległy dysponentowi uzyskuje dalsze informacje o ostatecznych kwotach przysługujących mu środków finansowych w roku budżetowym ${ }^{41}$.

Przyjęte regulacje odpowiadające zasadzie przejrzystości finansów publicznych znajdują potwierdzenie w corocznie uchwalanej ustawie lub uchwale budżetowej. Ustawowo wymagana przejrzystość jest osiągana w ramach tabelek będących załącznikami odpowiednio zamieszczonych w ustawie budżetowej ${ }^{42}$ lub uchwałach budżetowych ${ }^{43}$.

\section{Organy administracji publicznej a jawność i przejrzystość finansów publicznych}

W znaczeniu regulacji finansowych konieczność dostępu do informacji należy wiązać z omówionymi już przepisami wynikającymi z rozdziału 4 u. o f.p. Jednakże chcąc wskazać konkretne podmioty, organy, czasem jednostki zapewniające tę jawność i przejrzystość, należy oprzeć swoje rozważania na wszystkich regulacjach wynikających z u. o f.p. Na ich podstawie można hierarchicznie uporządkować obowiązki tych organów administracji publicznej w zakresie analizowanej jawności i przejrzystości finansów publicznych.

W tym zakresie wydaje się, że najważniejszym organem jest rząd. Rada Ministrów (w świetle art. 134 u. o f.p.) określa, w drodze rozporządzenia, szczegółowy sposób i tryb finansowania inwestycji z budżetu państwa. Do rządu należy także określenie wysokości kwot dotacji w kolejnych latach realizacji inwestycji, a w szczególności: warunków finansowania inwestycji ze środków budżetu pań-

39 Art. 114 ust. 6 u. o f.p.

40 Art. 2 pkt 8 u. o f.p.

41 Wyjątkiem jest budżet jednostki samorządu terytorialnego, w którym nie istnieje potrzeba dzielenia środków na części budżetowe, a jedynie działy, rozdziały i paragrafy — tożsame z budżetem państwa.

42 Zob. np. ustawa budżetowa z dnia 1 lutego 2019 roku, Dz.U. poz. 198.

43 Uchwała nr III/47/2018 Rady Miasta Rzeszowa z dnia 18 grudnia 2018 roku w sprawie uchwały budżetowej Miasta Rzeszowa na 2019 rok; uchwała nr IV/28/19 Rady Powiatu Rzeszowskiego z dnia 18 stycznia 2019 roku — uchwała budżetowa na rok 2019; uchwała nr IV/ 57/19 Sejmiku Województwa Podkarpackiego z dnia 28 stycznia 2019 roku w sprawie budżetu Województwa Podkarpackiego na 2019 rok. 
stwa i ocena efektywności ich wykorzystania, sposobu przekazywania środków budżetu państwa przewidzianych na finansowanie inwestycji oraz sposobu rozliczania inwestycji finansowanych ze środków budżetu państwa - z uwzględnieniem zasady, że łączna kwota środków z budżetu państwa nie może być wyższa niż wartość kosztorysowa inwestycji określona przy rozpoczęciu jej realizacji, obejmująca koszty przygotowania do realizacji, koszty robót budowlanych, koszty nadzoru nad wykonywaniem robót budowlanych i koszty pierwszego wyposażenia oraz z uwzględnieniem warunków dokonywania wydatków przez państwowe jednostki budżetowe i zasad udzielania dotacji na realizację inwestycji innym jednostkom.

Z kolei minister finansów podaje do publicznej wiadomości zbiorcze dane dotyczące: ogółu operacji finansowych sektora finansów publicznych, obejmujące w szczególności dochody i wydatki, przychody i rozchody, zobowiązania i należności, gwarancje i poręczenia; wykonania budżetu państwa za okresy miesięczne, w tym kwotę deficytu lub nadwyżki. Minister podaje także do publicznej wiadomości informacje obejmujące wykaz udzielonych przez Skarb Państwa poręczeń i gwarancji, wskazując osoby prawne i fizyczne oraz jednostki organizacyjne niemające osobowości prawnej, których te poręczenia i gwarancje dotyczą. Do niego także, na mocy art. 210 ust. 1 u. o f.p., należy prowadzenie rejestru tak zwanych podmiotów wykluczonych ${ }^{44}$ oraz udostępnianie o tym informacji instytucjom zarządzającym, organom pełniącym funkcję odpowiednio Krajowego Punktu Kontaktowego lub Krajowej Instytucji Koordynującej w programach finansowanych ze środków zagranicznych, instytucjom pośredniczącym, operatorom programów, instytucjom wdrażającym, instytucji certyfikującej, a także beneficjentom w zakresie ich własnego statusu. Zgłoszenie podmiotu do rejestru, uzyskiwanie informacji z tego rejestru oraz udostępnianie i przekazywanie informacji zawartych $\mathrm{w}$ tym rejestrze, $\mathrm{z}$ wyjątkiem udostępniania i przekazywania informacji beneficjentom, odbywa się za pośrednictwem elektronicznej platformy usług administracji publicznej ePUAP, o której mowa w przepisach o informatyzacji działalności podmiotów realizujących zadania publiczne.

Inny organ administracji publicznej - minister właściwy do spraw informatyzacji — na mocy art. 19a ust. 2a w zw. z ust. 3 ustawy z dnia 17 lutego 2005 roku o informatyzacji działalności podmiotów realizujących zadania publiczne ${ }^{45}$ na wniosek banku krajowego lub innego przedsiębiorcy udziela zgody na nieodpłatne wykorzystywanie do identyfikacji i uwierzytelniania w ePUAP środków identyfikacji elektronicznej stosowanych do uwierzytelniania w systemie teleinformatycznym banku krajowego lub innego przedsiębiorcy, po spełnieniu przez bank krajowy lub innego przedsiębiorcę warunków i zakresu korzystania z ePUAP.

W tym miejscu nie należy także zapominać o obowiązkach organów administracji publicznej w zakresie spraw podatkowych, które przecież również wiążą się

44 Na podstawie art. 207 u. o f.p.

45 Tekst jedn. Dz.U. z 2019 r. poz. 700 ze zm. 
z zapewnieniem jawności i przejrzystości funkcjonowania finansów publicznych. W tym zakresie Dyrektor Izby Administracji Skarbowej ogłasza w Wojewódzkim Dzienniku Urzędowym wykaz osób prawnych i fizycznych oraz jednostek organizacyjnych niemających osobowości prawnej, którym umorzono zaległości podatkowe, odsetki za zwłokę lub opłaty prolongacyjne w kwocie przewyższającej 5000 złotych wraz ze wskazaniem wysokości umorzonych kwot i przyczyn umorzenia.

Także naczelnik urzędu skarbowego (działający na podstawie ustawy z dnia 29 sierpnia 1997 roku Ordynacja podatkowa ${ }^{46}$ ) wydający decyzje o umorzeniu niepodatkowych należności budżetu państwa podaje informację kwartalną o udzielonych umorzeniach do publicznej wiadomości na swojej stronie podmiotowej w Biuletynie Informacji Publicznej do końca miesiąca następującego po zakończeniu kwartału. Podczas gdy w przypadku szczebla samorządowego zarząd jednostki samorządu terytorialnego (w wypadku gminy wójt, burmistrz, prezydent miasta) podaje do publicznej wiadomości w terminie do końca miesiąca następującego po zakończeniu kwartału między innymi: kwartalną informację o wykonaniu budżetu jednostki samorządu terytorialnego, w tym kwotę deficytu albo nadwyżki, oraz o udzielonych umorzeniach niepodatkowych należności budżetowych; wykaz osób prawnych i fizycznych oraz jednostek organizacyjnych nieposiadających osobowości prawnej, którym w zakresie podatków lub opłat udzielono ulg, odroczeń, umorzeń lub rozłożono spłatę na raty w kwocie przewyższającej łącznie 500 złotych wraz ze wskazaniem wysokości umorzonych kwot i przyczyn umorzenia; wykaz osób prawnych i fizycznych oraz jednostek organizacyjnych niemających osobowości prawnej, którym udzielono pomocy publicznej.

Wreszcie warto wspomnieć, że także Prezes Głównego Urzędu Statystycznego ogłasza, w formie komunikatu w Dzienniku Urzędowym Rzeczypospolitej Polskiej „Monitor Polski” w terminie do 16 kwietnia, wynik nominalny sektora instytucji rządowych i samorządowych podawany do wiadomości publicznej zgodnie z art. 7 rozporządzenia Rady (WE) nr 479/2009 z dnia 25 maja 2009 roku o stosowaniu Protokołu w sprawie procedury dotyczącej nadmiernego deficytu załączonego do Traktatu ustanawiającego Wspólnotę Europejską47 za ostatnie cztery lata, wykazując przy tym łączną dynamikę wartości produktu krajowego brutto w cenach stałych za ostatnie sześć lat.

\section{Podsumowanie}

Obowiązujące regulacje prawne świadczą o niemożności pomijania informacji o działalności organów administracji publicznej w aspekcie zapewnienia

46 Tekst jedn. Dz.U. z 2019 r. poz. 900 ze zm.

47 Dz. Urz. UE L z 10.06.2009, s. 145 ze zm. (dalej: wynik nominalny). 
jawności i przejrzystości finansów publicznych. Jak wykazano, zarówno organy administracji rządowej, jak i samorządowej czynnie uczestniczą w bieżącym dostarczaniu informacji wszystkim obywatelom. W tym zakresie ich działanie jest nieodzowne, przez co trudno wyobrazić sobie sytuację, w której organy administracji publicznej nie realizowałyby swoich zadań publicznych związanych z przekazywaniem informacji dotyczących środków publicznych. Tę działalność potwierdzają wskazane, bardzo liczne, publikatory oraz możliwość osobistego pozyskiwania informacji przez obywateli, co można przyjąć za wnioski de lege lata.

W ramach postulatów de lege ferenda należy wskazać, że organy administracji publicznej nadal powinny dążyć do zagwarantowania pełnej dostępności do informacji dotyczących środków publicznych, w szczególności ich wydatkowania. Chcąc bowiem współdziałać z obywatelami w zapewnieniu jawności i przejrzystości finansów publicznych, organy administracji publicznej powinny doskonalić już istniejące bazy informacyjne, a także wprowadzać nowe. Warte rozważenia jest natomiast pewne usystematyzowanie już istniejących baz danych, aby ułatwić każdemu obywatelowi dostęp do informacji związanych ze środkami publicznymi.

\section{Bibliografia}

Begg D., Fischer S., Dornbusch R., Mikroekonomia, Warszawa 2007.

Chwalba A., Basista J., Czekalski T., Poleski J., Stopka K., Dzieje Polski. Kalendarium, Kraków 2000.

Denek E., System budżetowy i gospodarka budżetowa państwa, [w:] Finanse publiczne, red. E. Denek, Warszawa 1997.

Dych Z., Szopa B., Encyklopedia zarządzania, Kraków 2004.

Gajl N., Finanse i prawo finansowe, Warszawa 1986.

Gella A., Zagłada Drugiej Rzeczypospolitej 1945-1947, Warszawa 1998.

Gliniecka J., Przejrzystość i jawność jako reguly gospodarowania publicznymi środkami pieniężny$m i$, „Gdańskie Studia Prawnicze” 2015, nr 33.

Jaśkiewiczowa J., Prawo finansowe, Gdańsk 1990.

Kędzierska K., Prawo do informacji w polskim porzadku prawnym, [w:] Dostęp do informacji publicznej a prawo do prywatności, red. A. Gałach, K. Kędzierska, A. Lipiński, B. Opaliński, B. Pietrzak, P. Szustakiewicz, A. Zołotar-Wiśniewska, Warszawa 2015.

Kopaliński W., Słownik wyrazów obcych i zwrotów obcojęzycznych z almanachem, Warszawa 2000. Kumaniecki K., Stownik łacińsko-polski, Warszawa 1986.

Maneli M., O funkcjach państwa, Warszawa 1962.

Morawski W., Zmiana instytucjonalna, Warszawa 2000.

Mucha M., Obowiązki administracji publicznej w sferze dostępu do informacji, Wrocław 2002.

Paczkowski A., Stanisław Mikołajczyk, czyli klęska realisty (zarys biografii politycznej), Warszawa 1991.

Patrzałek L., Finanse samorządowe, Wrocław 1999.

Pirożyński Z., Budżet państwowy w projekcie Konstytucji, „Finanse” 1952, nr 2.

Roszkowski W., Najnowsza historia Polski 1914-1945, Warszawa 2003. 
Rozmaryn S., Polskie prawo państwowe, Warszawa 1951.

Ruśkowski E., Stankiewicz J., Budżety jednostek samorzadu terytorialnego, [w:] Finanse publiczne i prawo finansowe, red. E. Ruśkowski, Warszawa 2000.

Sokalska E., Organizacja lokalnego aparatu administracyjnego $w$ Polsce $w$ latach 1957-1975, „Studia Prawnoustrojowe” 2005, nr 4.

Stourme R, Le budget, Paris 1913.

Szumiło M., Roman Zambrowski 1909-1977, Warszawa 2014.

Weremiuk S., Specyfika stosunków polsko-radzieckich w okresie 1944-1991, „Przegląd Bezpieczeństwa Wewnętrznego" 2014, nr 11.

Wielki stownik języka polskiego, Warszawa 2006.

Wierzbicki J., Wolniak J., Finanse w socjalizmie — zarys teorii, Warszawa 1979.

Zdzitowiecki J., Zasady budżetowe w Konstytucji Polskiej Rzeczypospolitej Ludowej, https://repozytorium.amu.edu.pl/bitstream/10593/15335/1/003\%20JAN\%20ZDZITOWIECKI\%20 RPEiS\%2020\%282\%29\%2C\%201958.pdf (dostęp: 2.03.2019).

\title{
Inaction of public authority bodies in the public finance concerning the disclosure of information in Poland
}

\author{
Summary
}

Showing chosen signs of the activity of public authority bodies is the subject of the study in information delivery regarding public finance in Poland, in order to prove the thesis impossibilities of omitting the workings of both government and local government bodies of public authority on every functioning plan of the state.

Analysis of the chosen issues will be conducted based on one of the budgetary principles - the principle of openness of the budget. Due to the extension of its meaning also to the openness and transparency of public finance, deliberations will be based about previous and currently effective laws and regulations in the context of the workings of public authority bodies.

Legal regulations being in force connected above all with public finance but also arising from other normative acts, chosen will constitute the base of deliberations positions of the literature on the subject and the judicature.

Keywords: public authority bodies, the principle of openness and transparencies of public finance, access to public information. 